\title{
Editorial
}

\section{OS DISTRITOS GEOEDUCACIONAIS}

Em cumprimento de artigos da Lei $n .^{\circ} 5: 540 / 68$, por ato normativo do Ministério da Educação e Cultura e para os fins que determina, está o País dividido em Distritos Educacionas. Dezoito Unidades da Federação (inclusive Guanabara e Distrito Federal) cada um constitui-se em um Distrito Geoeducacional, sendo que aos do Amazonas, Pará e Mato Grosso juntaram-se respectivamente os Territórios de Roraima, Amapá e Rondônia. Cinco Estados - Minas Gerais, Rio de Janeiro, S. Paulo, Paraná e Rio Grande do Sul têm respectivamente seis, dois, oito, dois e quatro Distritos. Ao todo são 41 os Distritos Geoeducacionais.

Qual a finalidade de criarem-se os Distritos? Para planejamento e expansão da rede de ensino. Serão utilizadas as perspectivas distritais para o planejamento educacional, inclusive para a tomada das decisões respectivas. As estatísticas poderão ser mais bem interpretadas por essa perspectiva do que pela antiga referência estadual apenas.

Em cada Distrito foram, em gradiente decrescente classificadas cidades como Grande Pólo, Pólo, Núcleo Germinal e Surgência. Cada Distrito, em geral, compreende um Grande Pólo ou Pólo; criaram-se, desse modo, condições operacionais para planejamento educacional a fim de adequarem-se medidas às necessidades.

Para os estudos futuros de formação de pessoal de enfermagem, a rede dos Distritos Geoeducacionais - estudando-se as metas que se iniciem nos Grandes Pólos e daí por diante - poderá facilitar o planejamento. Mesmo sendo carentes no ensino de enfermagem as instituições de ensino de todos os graus, o modo de planejar assim determinado traz esperança de um futuro melho. (HGD). 